О. В. Слюніна

\title{
ЛІНГВОСОФСЬКЕ ОСМИСЛЕННЯ ПРИРОДНОЇ СТИХІЇ ВОГОНЬ: ЕТИМОЛОГІЧНИЙ ТА СЕМАНТИЧНИЙ АСПЕКТИ
}

\footnotetext{
Слюніна О.В. Лінгвософське осмислення природної стихії вогонь: етимологічний та семантичний аспекти.

Стаття присвячена лінгвософським проблемам, які торкаються феномену репрезентації архетипних уявлень у мові. Крізь призму фактологічних знань лінгвістики, філософії, культурології, когнітології аналізується архетипний концепт вогонь, його поняттєва і культурна складові.

Ключові слова: архетипний концепт, вогонь, семантична сфера, семантичне наповнення, етимологічний шар.

(C) О. В. Слюніна, 2011.

$-438-$
} 
Слюнина Е. В. Лингвософское осмысление природной стихии огонь: этимологический и семантический аспекты.

Статья посвящена лингвософским проблемам, касающихся феномена репрезентации архетипных представлений в языке. Сквозь призму фактологических знаний лингвистики, философии, культурологии, когнитологии анализируется архетипный концепт огонь, его понятийный и культурный шары.

Ключевые слова: архетипный концепт, огонь, семантическая сфера, семантическое наполнение, этимологический шар.

Sljunina O. V. Linguosophical analysis of the element fire: etymological and semantic aspects.

The article focuses on the linguosophical problems connected with the verbal representation archetypical knowledge. Based on the lingual, philosophical, cultural and cognitive paradigms the author tends to analyze the verbal representation of archetypical concept fire.

Key words: archetypical concept, fire, semantic sphere, semantic filling, etymological sphere.

Видається можливим, що більшість 3 тих смислів, які часто дослідники художньої творчості інтерпретують як індивідуальноавторські, суб'єктивні інтенції письменника, насправді мають підгрунтям архетипи. Доречною у цьому контексті постає думка французького філософа та психоаналітика Г. Башляра, яку він висловлює, роздумуючи над взаємозв'язком окремих поетичних образів 3 мовою: «Архетип $\epsilon$ причиною всього безпричинного, надто часто першопричиною, що миттєво висвітлює небагату історію психології з поезією» [3, с. 78]. За думкою К.Г.Юнга, Е. Ноймана та інших психологів, архетипи найяскравіше виражаються у снах, міфах і художній творчості.

Зважаючи на те, що свідомість людини є надзвичайно складним феноменом, при дослідженні мовного вираження архетипних уявлень, уважаємо за доцільне говорити про архетипний конщепт, у структурі якого виокремлюються як універсальні, загальномовні, так i архетипні, загальнокультурні смисли (які часто визначаються як загальнопоетичні), а також індивідуально-авторська інтерпретація.

Метою цієї статті є дослідити культурологічну складову архетипного концепту вогонь в українській мовній картині світу, зосередивши увагу на етимологічному та історичному шарах. Поставлена мета конкретизується в таких завданнях: визначити ядро архетипного концепту вогонь, його поняттєву складову за допомогою звернення до тлумачних словників; з'ясувати етимологію слів-репрезентантів; проаналізувати історичний шар через вивчення міфологічних, релігійних та натурфілософських даних; змоделювати основні семантичні сфери та окреслити семантичні наповнення архетипного концепту вогонь.

Серед досліджень, які стосувалися особливостей вербалізації природної стихії вогню, варто відзначити дисертації Л. В. Педченко, А. В. Трофімової, грунтовні статті В. Г. Приходько, Н. В. Сиромлі, I. В. Яковенко. Торкаються проблем вербалізації вогню і С. О. Белевцова, О. О. Борискіна та О. О. Кретов, Т. В. Федотова, Н. В. Чендей.

Для визначення ядра архетипного концепту вогонь послуговуємося відомостями 3 тлумачних словників. Зокрема, у «Словнику української мови» в 11-ти томах слово-ім'я архетипного концепту вогонь має такі 
дефініції: «1. Розжарені гази, що виділяються під час горіння й світяться сліпучим світлом; полум'я. 2. перен. Душевне піднесення, натхнення. // Пристрасть, запал. // Про того, хто має дуже енергійну, запальну вдачу. 3. Вогнище. 4. Світло сонця, освітлювальних приладів. // перен. Блиск очей, що звичайно відображає якийсь внутрішній стан людини. 5. розм. про жар, підвищену температуру тіла. 6. Стрільба з гвинтівок, гармат і т. iн. 7. Військова команда для здійснення пострілу; наказ стріляти» [24, c. 715-716].

Аналіз лексикографічних джерел дозволяє виокремити у структурі архетипного концепту вогонь такі семантичні сфери, як ВОГОНЬ ДЖЕРЕЛО ТЕПЛА І СВІТЛО з семантичнимИ наПовненнями вогонь полум'я та вогонь - світло; семантичну сферу ВОГОНЬ - ЕМОЦІЙНИЙ СТАН, яку формують семантичні наповнення вогонь - пристрасть, вогонь - натхнення, вогонь - запал; семантичну сферу ВОГОНЬ РУЙНАЦІЯ (де найповніше експлікується функціональне призначення вогню - для знищення).

Стосовно сфери ВОГОНЬ - ЕМОЦІЙНИЙ СТАН, то ії доповнюють такі архетипні семантичні наповнення, як вогонь - кохання та вогонь гнів. Щодо першого, то О. О. Потебня на підтвердження усталеності такого осмислення наводить прислів'я: ««Любов - не пожежа, а загориться - не загасиш»; з подібних неповних порівнянь, - зазначає дослідник, - можна завжди майже зробити висновок і про існування повних, тобто в нашому випадку, що любов є пожежею» [21, с. 18]. Вогонь як символ кохання присутній у світовій літературі в багатьох шедеврах різних письменників, на що вказує Л. О. Пустовіт: «Участь слова у реалізації семантичної моделі поетичного словосполучення вогонь (полум'я) кохання, його належність до відповідного словесно-асоціативного ряду (вогонь, полум'я) свідчить про традиційно символічне значення слова вогонь, що може бути наслідком семантичного стягнення фразеологічного словосполучення - усталеного засобу поетичної мови» [22, с. 38$]$.

Про усталеність семантичного наповнення вогонь - гнів ідеться у роботі I. В. Яковенко. У статті дослідниці наголошується, що досить часто в художніх творах «психологія гніву проступає на тлі стихії вогню» [33, с.552]. Ця думка наявна i в грунтовній праці О. О. Потебні, що присвячена аналізу символів слов'янської поезії: «Гнів $є$ вогонь; і від нього серце розгоряється «сильніше, ніж від вогню» <..> Взагалі у словах для гніву і споріднених з ним понять домінує уявлення вогню» [21, с. 20]. На підтвердження своєї думки мовознавець наводить такі ілюстрації: старочеське skravada - «сварка», «ворожнеча» та чеське skravad «сковорода», що походить від скврътн, скваръ - «жар»; чеське hašteřiti se - «сваритися» та ha-štra - «лучина, що горить»; російське гнев та польське niecić і чеське nítiti - «запалювати» [21, c. 20-21]. 
Розглянувши поняттєву складову, ядерні компоненти архетипного концепту вогонь в українській мові, перейдімо до окреслення семантичних наповнень, що становлять приядерну частину. Для цього звернімося до даних етимологічних джерел, оскільки смислове наповнення концепту спирається на етимологічний аналіз його вербалізаторів. Ця інформація дозволяє виявити глибинний шар, який покладено в основу смислового простору концепту. Наразі серед учених немає одностайності щодо походження слова вогонь. В «Етимологічному словнику української мови» вказується, що іменник вогонь, як і інші назви на позначення природних стихій, належить до найдавніших прошарків лексики i присутній у більшості слов'янських мов. Порівняймо: у давньоруській (огнь), в російській (ого́нь), білоруській (аго́нь), польській (ogień), чеській та словацькій (oheň), верхньолужицькій (woheń), нижньолужицькій (wogeń), полабській (vid’ěn), болгарській (о́гнъ), македонській (оган), сербохорватській (о̀ань), словенській (ógenj). Згідно з даними словника, слово походить зі старослов'янського огнь, яке у свою чергу утворилося від праслов’янського іменника * $\operatorname{ogn}(j) b[13$, с. 413-414]. I. I. Срезневський вихідною формою слова вогонь пропонує вважати литовське ugnis чи латинське ignis [25, с. 605]. Подібні міркування висловлює й М. Фасмер. У його словнику зазначено, що «и- - результат редукції $o-$, судячи 3 лит. agnùs - «вогняний»« [29, с. 118]. Такі думки О. М. Трубачову видаються непереконливими. Він стверджує, що індоєвропейське *ignis є своєрідним неологізмом, яке утворилося від *ngnis і відображає ідею ритуального поховального вогнища [28, с. 211]. А. Мейє стверджує, що в усі мови вогонь потрапило з санскритського agnih [18, с. 345]. Отже, серед дослідників на сьогодні не існує єдності щодо походження слова вогонь.

Так само, як і в «Етимологічному словнику української мови», у словниках М. Фасмера, П. Я. Черних, Я. Б. Рудницького походження слова вогонь виводиться від індоєвропейської прамови: **egnis, *ognis, звідки воно потрапило до давньоіндійської (agnih) хетської (agniš), латинської (ignis), литовської (ugnis) та інших мов [13, с. 413-414], [23, с. 458]. П. Я. Черних зазначає, що в хетській мові Agniš означало ім'я бога [32, с. 592]. Таким чином, думка Т. А. Космеди та Н. В. Плотнікової, про те, що «іменник вогонь у значенні вогонь як предмет поклоніння має дуже давнє походження» [15, с. 125] і про те, що архетипний концепт вогонь «у своїй концептуальній структурі міг містити смисловий елемент «божество»« [15, с. 125] видається цілком правомірною. Як бачимо, згідно 3 даними етимологічних джерел, виформовується семантичне наповнення вогонь - божество. Ці міркування підтверджуються міфологічними уявленнями давніх людей, адже стихія вогню часто наділялася надприродними здібностями - в язичницьких вірування божества вогню посідають одне з чільних місць. Наприклад, у зороастризмі вогонь є сином верховного бога Ахура-Мазда, в Індії шанували бога Агні. У грецькій 
натурфілософії Емпедокл персоніфікував вогонь як Зевса, а на слов'янських теренах культ вогню був представлений поклонінням Дажбогу, Перуну та Сварогу. Вогонь надзвичайно шанувався українцями. Як зазначає Х. К. Вовк: «Вогонь вважають святим; до нього почувають особливу повагу, кожна господиня мусить ставитись до вогню дуже обережно та 3 пошаною; при ньому не можна говорити щось непристойне, в нього не можна плювати або кидати щось нечисте, з ним не можна гратись, не можна навіть вимітати піч тим самим віником, що ним замітають хату. «Ми шануємо вогонь, як бога; він наш дорогий гість». Переховались навіть деякі сліди колишніх жертв йому» [10, с. 175]. Цікавими в цьому плані постають думки М. М. Маковського про спорідненість слів зі значенням «вогонь' та «горіти' зі словами зі значенням «поклонятися божеству': індоєвропейське *egnis «вогонь», але індоєвропейське *iag- «поклонятися божеству» та індоєвропейське *eg- «говорити, молитися»; індоєвропейське *bhaud- «горіти», але давньоанглійське boedan «просити, молити» [17, c. 243]. Отже, семантичне наповнення вогонь - божество може бути одним з перших конституентів семантичної сфери ВОГОНЬ - ЖИВА ICTOTA. Цікавим видається визначення вогню, запропоноване в «Енциклопедії символів» Г. Бідермана: «Вогонь - стихія, що здається живою» [7, с. 184].

На відміну від води, вогонь у багатьох культурах мислився як чоловічий елемент. Тож, до семантичної сфери ВОГОНЬ - ЖИВА ІСТОТА буде доцільним включити й таке семантичне наповнення, як вогонь людина, тим паче, що це архетипне уявлення знаходить своє втілення на рівні будови слів у різних мовах. Зокрема, М. М. Маковський зіставляє індоєвропейський корінь *pu- - «чоловік, чоловічий» та грецьке $\pi v \rho-$ «вогонь»; латинське vir - «людина, чоловік», але індоєвропейське *uer- «горіти»; німецьке Kerl - «людина, чоловік», але індоєвропейське *ker- «горіти»; давньоанглійське secg - «людина, чоловік», але осетинське sugyn - «горіти»; індоєвропейське *ar- - «чоловічий, чоловік», але в той же час і «горіти» [17, с. 243]. Слов'янам також була властива персоніфікація стихії. Як зазначає О. Л. Мадлевська, люди настільки шанували вогонь, що на Вологодщині називали вогонь «батюшкою» [16, с. 180] або «царем» [16, с. 182]. У спільній монографії Т. А. Космеда та Н. В. Плотнікова висувають гіпотезу, що «первісно іменник изар використовувався як епітет до іменника вогонь та писався окремо, а на момент виникнення повних членних форм прикметників номінація цุар вогонь стала загальновживаною й іменник цุар не перетворився на повний прикметник, а почав уживатись як іменник прикладкового характеру, який сьогодні, згідно з нормами сучасного правопису, пишеться через дефіс - ияар-вогонь» $[15$, с. 128]. Отже, цими ілюстраціями доводиться архетипність такого семантичного наповнення, як вогонь - людина. 
Важливими є думки А. Мейє, який пропонує розмежовувати слова на позначення вогню «одухотвореного» та вогню «неживого»: «В індоєвропейській все, що рухається, все, що діє тим самим підпадає під поняття «живого». Трапляється навіть, що певному поняттю можуть відповідати два імені: одне «живого» роду, інше «неживого»« [18, с. 345]. Учений наводить такі слова на позначення «живого», «розумного» вогню в різних мовах: грецьке $\pi \nu \rho$, умбрське pir, давньонімецьке fiur, латинське ignis, давньослов'янське огмь [18, с. 345]. Уявлення про «два вогні» присутнє у вченні Геракліта: «Геракліт розрізняв свій вічно живий першовогонь від вогню, як звичною форми стану першоречовини, i,

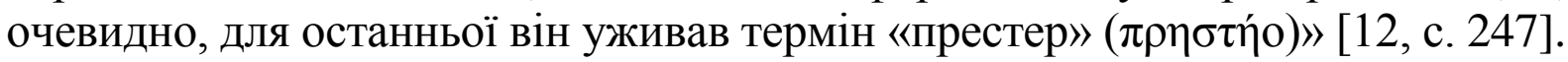

Нерідко образ вогню супроводжує різних казкових істот. Зокрема, у фольклорній традиції образ змії має вогняну природу [34, с. 73]. Наприклад, Змій-Горинич наділяється здатністю дихати вогнем. Про спорідненість двох образів пише А. В. Трофімова [27, с. 107]. Цю думку доводить М. М. Маковський, зазначаючи, що «в низці випадків значення «вогонь» співвідноситься зі значенням «змія»« $[17$, с. 240]. Учений наводить такі приклади з різних мов: латиське kaitēt - «горіти», але чеське had i російське гад; індоєвропейське *ater- - «горіти», але англійське adder - «змія»; готське waurms - «змія», але англійське warm, німецьке warm - «теплий», індоєвропейське *uer- - «горіти» [17, с. 240]. До цього можна додати ще той факт, що від слів на позначення вогню та горіння походять також назви деяких плазунів: вогнівка, жигальниця.

М. В. Зав’ялова підкреслює, що «змія має і візуальну подібність 3 вогнем: повзає по землі, як вогонь, пече та обпалює» [14, с. 387]. Про спорідненість двох образів - вогню та змія - писав О. О. Потебня: «Символи злості: змія, оса, кропива - жалять, тобто палять. Про відношення змії до вогню свідчать багато повір’їв і виразів, як наприклад, змія «по траві повзе - мураву сушить» [21, с. 21].

За спостереженнями М. В. Зав’ялової, «цікаво переплітаються зміїна та пташина природа, в результаті чого виникає Вогняний Летючий Змій, котрий є втіленням стихї вогню» [14, с. 378]. Зі стихією вогню в багатьох культурах (у тому числі й в українській) тісно пов'язаний i образ вогняного птаха, жар-птиці, що заснований на метафоричному перенесенні за ознакою швидкості - вогонь летить: «птах - вогонь бушуючий, палючий, летючий» [14, с. 381]. Саме тому в деяких мовах «значення «горіти» може також зіставлятися зі значенням «літати» [17, с. 240]. У зв’язку із цим М. М. Маковський пропонує порівняти давньоанглійське lieg «вогонь» та німецьке fliegen «літати»; російське nápumь, але napúmь тощо [17, с. 240]. На українських теренах традиційною метафорою за формою є зіставлення полум'я з крилом. Уявлення вогню в образі птаха Г. Башляр зіставляє з міфом про чарівного фенікса («Сліпучий птаха - це первинний образ Фенікса» [4, с. 53]), який «спалахує від свого ж вогню і 
відроджується 3 власного ж попелу» [4, с. 49]. У структурі архетипного концепту вогонь у межах семантичної сфери ВОГОНЬ - ЖИВА ICТОТА виокремлюємо ще одне семантичне наповнення вогонь - тварина.

Вогонь здавна був також символом роду. Зокрема, Д. М. ОвсяникоКуликовський зазначає, що в кожному домі арійців «горів священний вогонь, що належав сім’ї або роду. Сім’ї групувалися в общини, і кожна община мала свій особливий вогонь, який був іï патроном і слугував основою суспільного культу» $[19$, с. 3]. Дослідник також виокремлює різні назви на позначення родинного, общинного, союзного вогню. «Агні домашній - це, так би мовити, центр, навкруг якого групується родина, до якого тяжіє все життя іiі, - основа, на якій утверджуються іiі устої. Агні домашній - божество шлюбу. Он скріплює сімейний союз, підтримуючи злагоду між чоловіком та жінкою» [19, с. 31]. Відповідно, його супроводжують епітети damūnas - домашній, grhapati, dveshoyul - той, що видаляє все недружнє, прибирає ворожість між родиною [19, с. 32].

Архетипний смисл вогонь - родина, за словами О. М. Афанасьєва, легко пояснити слов'янським поклонінням вогню: «Усякий мандрівник, іноплемінник, входячи під дах певного дому, вступав під захист його пенатів; сідаючи біля вогнища, віддаючись під охорону розведеного в нім вогню, він тим самим ставав ніби членом родини, - подібно до того як i наречена, яку приводили в дім нареченого, тільки тоді долучалася до його родичів, коли тричі обходила навколо затопленої печі» [3, с. 180-181]. Порівняймо у зв'язку із цим: російське пламя, але племя, давньоанглійське tiohh - «рід», але англійське stock - «рід», осетинське tug - «кров»; індоєвропейське *kel- - «горіти», але давньоіндійське kula- - «рід» $[17$, с. 240$]$. У роботі Д. М. Овсянико-Куликовського зазначено, що слово angiras є епітетом священного вогню, однак у той же час у множині може означати родину, сім'ю [19, с. 61]. Схожі міркування висловлює Д. П. Амичба, стверджуючи, що вогонь та родина, дім - це «поняття, які знаходяться на одному ментальному рівні» $[1$, с. 32] не лише в слов’янських, але й у тюркських мовах. Тож, цілком закономірним буде віднести до структури архетипного концепту вогонь i такий смисл, як вогонь-родина.

Одухотворені образи вогню спостерігаються в стертих предикативних метафорах, на кшталт: вогонь засинає, вогонь пожирає, вогонь розводиться, вогонь сичить; у генітивних метафорах: язики полум'я, крило вогню; в епітетних сполуках: живий вогонь, жива ватра, швидкий вогонь, изар-вогонь.

Усвідомлення вогняної стихї як ефірної субстанції належить до найдавніших уявлень людини. У доктринах Геракліта вогонь зближався 3 повітрям: «його першовогонь тотожний чистому повітрю» [12, с. 236], а отже, згідно з його ученням, люди дихають вогнем. У християнстві вогонь над головами символізує одкровення, сходження божественної енергії 
(пригадаємо, що сходження Святого Духа в день П’ятдесятниці в Новому Заповіті змальовується у вигляді полум'яних язиків).

М. М. Маковський вказує на зближення значення слова вогонь у деяких мовах зі значенням «жити»: індоєвропейське ker- - «горіти», але осетинське coeryn - «жити», давньоіндійське as «життя, жити», але індоєвропейське *eus- - «горіти» [17, с. 77]. Таким чином, виокремлюємо смисл вогонь - жсиття.

Ще одним усталеним смислом, який супроводжує архетипний концепт вогонь у традиціях різних народів, $є$ усвідомлення очисної сили стихії. У роботі О. М. Трубачова підкреслюється спорідненість назв вогню 3 латинським pūrus - «(ритуально) чистий, давньоіндійським puná̀ti «очищати» [28, с. 211]. Такий етимологічний зв’язок, на думку мовознавця, «дозволяє осмислити назву вогню i.-€: *pe or / *punos як перошопочатковий атрибутив «чистий, очищаючий'» [28, с. 211]. Цей смисл, за спостереженнями М. М. Маковського, наявний i в давньоіндійській мові: pavanas - «той, що очищує», але також і «вогонь»; у грецькій $\pi v \rho$ - «вогонь», але латинське purus - «чистий»; індоєвропейське *ar- - «горіти», але хетське $\operatorname{arr}$ - - «мити, очищувати» [17, с. 241].

У більшості есхатологічних міфів, що передрікають жахливу катастрофу, все живе гине в полум’і. Ці думки перегукуються й 3 біблійним твердженням, що кінець світу настане в результаті світової пожежі (яка, до речі, символізує очищення світу від зла). Відповідно, вогонь постає символом знищення. Отже, у структурі архетипного концепту вогонь виокремлюємо такий смисл як вогонь - знищення. Окрім цього, в пекельному вогні мучаться грішники та ангели, що не вберегли своєї божественної гідності.

До приядерної зони архетипного концепту вогонь належить також семантичне наповнення вогонь - одна 3 першостихій. У натурфілософських школах античності вогонь постав як один 3 першоелементів буття, як першостихія, з якої постав увесь видимий світ. На такі думки натрапляємо в доктринах Аристотеля, Емпедокла, Парменіда. Однак особливого значення у зв'язку 3 дослідженням архетипного концепту вогонь набувають філософські пошуки Геракліта Ефеського, котрого його сучасники і послідовники називали «Темним» через складність витворених ним концепцій. Геракліт основою всіх основ оголосив вогонь [2, с. 13], «мотивуючи це тим, що вогонь знаходиться у вічному русі й безперервно змінює своє обличчя, трансформується 3 одного стану в інший, зникає й знову відновлюється» [12, с. 238]. Вогонь у його натурфілософії розумний і зближується з поняттям Логосу. Геракліт увесь світ трактував як постійне згасання та розгоряння вогню. Згідно 3 його діалектичним ученням, усі інші природні стихії (земля, вода, повітря) виникають саме 3 вогню й у вогонь повертаються. В «Енциклопедії символів» О.В. Вовк зазначено, що «в міфології відблиски космічного 
полум'я освічують зародження та знищення Всесвіту. У космогонічних міфах, присвячених створенню світу, вогонь відіграє роль головної стихії, первинного матеріалу космогенезу (це, до речі, цілком відповідає теорії Великого вибуху, яку висунули вчені лише в середині XX століття) [9, с. 77]. Можливо, уявлення представників найперших філософських шкіл і спричинили таке осмислення стихії вогню, як першоелемент буття. На мовному рівні такі смисли М. М. Маковський пов'язує зі спорідненістю слів: грецького коб«вогнище»; давньоанглійського wang - «світ» та давньонімецького waehan «спалити»; індоєвропейського *ker- «горіти» та індоєвропейського *ker $(d)$ - «середина»; індоєвропейського *ater- - «вогонь» та давньоіндійського *ardha- - «середина, порядок, гармонія» [17, с. 240].

Розглянувши міфологічні та символічні уявлення людей про стихію вогню, можемо зробити висновок, що архетипний концепт вогонь у своїй структурі містить цілу гаму смислів, які можна вважати універсальними. Про це свідчить також асоціативний експеримент, проведений Д. Д. Хайрулліною серед носіїв англійської і татарської мови, оскільки його результати свідчать про усталеність архетипних смислів концепту вогонь. Єдине, з чим можна не погодитися з автором у висновках, - це те, що деякі 3 таких смислів, як-то, наприклад, називання вогню чоловічим елементом (в англійській мові) або називання вогню родинним вогнищем (у татарській мові) є етнокультурними особливостями, адже ці смисли наявні в багатьох мовних системах, про що мова йшла вище [30, с. 82-84].

Отже, ядро концепту становитимуть семантичні сфери ВОГОНЬ ДЖЕРЕЛО ТЕПЛА І СВІТЛА ( полум'я і вогонь - світло), а ВОГОНЬ - ЕМОЦИЙНИЙ СТАН (вогонь пристрасть, вогонь - натхнення, вогонь - запал), ВОГОНЬ РУЙНАЦІЯ (вогонь - війна). До приядерної частини відносимо семантичне наповнення вогонь - гнів у межах сфери ВОГОНЬ ЕМОЦІЙНИЙ СТАН; семантичне наповнення вогонь - знищення, яке доповнює семантичну сферу ВОГОНЬ - РУЙНІВНА СИЛА; семантичну сферу ВОГОНЬ - ЖИВА ІСТОТА (вогонь - божество, вогонь - людина, вогонь - тварина). Оскільки вогонь усюди мислився як священний i використовувався в містичних обрядодіях, при похованні, при хворобах, то вважаємо за можливе виокремити також семантичну сферу ВОГОНЬ САКРАЛЬНА СИЛА (3 семантичними наповненнями вогонь периостихія, вогонь - життя, вогонь - очищення).

Перспективним видається наукове дослідження особливостей вербалізації архетипного концепту вогонь у словесно-поетичній практиці різних художників слова з метою виявлення загальномовних, архетипних та індивідуально-авторських інтерпретацій, а також тих лінгвопоетичних засобів, якими послуговуються письменники при моделюванні різних смислових наповнень концепту. 


\section{Література}

1. Амичба Д. П. Концепт-конструкт «огонь» в ментальной образности абхазов / Д. П. Амичба // Ученые записки Таврического национального университета им. В. И. Вернадского. Серия : Филология. Социальные коммуникации. - 2011. - Т. 24(63). - № 2. Часть I. - С. 32-37.

2. Аристотель. Метафизика / Аристотель. - Ростов-на-Дону : Феникс, 1999. - 608 с.

3. Афанасьев А. Н. Древо жизни : [избранные статьи] / Александр Николаевич Афанасьев. - М. : Современник, 1982. - 464 с.

4. Башляр Г. Фрагменти Поетики Вогню / Гастон Башляр ; [пер. с. франц. Р. В. Мардера]. - Харків : Фоліо, 2004. - 143 c.

5. Бєлєхова Л. І. Словесний поетичний образ в історико-типологічній перспективі: лінгвокогнітивний аспект (на матеріалі американської поезії) : [монографія] / Лариса Іванівна Бєлєхова. Херсон : Айлант, 2008. - 368 с.

6. Біблія : [книги священного писання Старого та Нового завіту в українському перекладі 3 паралельними місцями та додатками] ; [пер. Патріарха Філарета]. - К. : Видання Київської Патріархії Української Православної Церкви Київського Патріархату, 2004. - 1408 с.

7. Бидерман Г. Энциклопедия символов / Ганс Бидерман ; [пер. с нем., общ. ред. и предислов. Свенцицкой И. С]. - М. : Республика, 1996. - 335 с.

8. Вернадский В. И. Философские мысли натуралиста / Владимир Иванович Вернадский. - М. : Наука, 1988. - 520 с.

9. Вовк О. В. Энциклопедия знаков и символов / Олег Викторович Вовк. - М. : Вече, 2006. - 528 с.

10. Вовк Х. К. Студії з української етнографії та антропології / Хведір Кіндратович Вовк. - К. : Мистецтво, 1995. - 336 с.

11. Голобородько К. Ю. Ідіостиль Олександра Олеся : лінгвокогнітивна інтерпретація : [монографія] / Костянтин Юрійович Голобородько. - Х. : Харків. історико-філол. т-ство, 2010. - 527, [1] с.

12. Досократики: доэлеатовский и элеатовский периоды : [пер. с древнегреч. А. О. Маковельского]. - Минск : Харвест, 1999. - 784 с. (Серия : Классическая философская мысль).

13. Етимологічний словник української мови : в 7 т. / АН УРСР, Ін-т мовознав. ім. О. О. Потебні ; [голов. ред. О. С. Мельничук]. - К. : Наукова думка, 1982-2006. - Т. 1 : А-Г. - 1982. - 631 с.

14. Завьялова М. В. Семантическое поле «огонь» в русских и литовских заговорах / М. В. Завьялова // Балто-славянские исследования 1997 : [сб. научных трудов]. - М. : Индрик, 1998. - С. 374-391.

15. Космеда Т. А. Лінгвоконцептологія: мікроконцептосфера святки в українському мовному просторі : [монографія] / Т. А. Космеда, Н. В. Плотнікова. - Львів : ПАІС, 2010. - 408 с.

16. Мадлевская Е. Л. Русская мифология : [енциклопедия] / Елена Леонидовна Мадлевская. - Спб. : Мидгард, 2005. - 781 с.

17. Маковский М. М. Сравнительный словарь мифологической символики в индоевропейских языках : Образ мира и миры образов / Марк Михайлович Маковский. - М. : Гуманит. изд. центр ВЛАДОС, 1996. - $416 \mathrm{c.}$

18. Мейе А. Введение в сравнительное изучение индоевропейских языков / Антуан Мейе ; [пер. с фрц. М. Кудрявского]. - М.-Ленинград : Государственное социально-экономическое издательство. 1938. $-510 \mathrm{c}$.

19. Овсянико-Куликовский Д. Н. Къ исторіи культа огня у индусовъ въ эпоху вһllдь / Дмитрий Николаевич Овсянико-Куликовский. - Одесса : Типографія «Одесскаго вhllстника», 1887. - 120 с.

20. Педченко Л. В. Лексика вогню в говірках російської мови. : автореф. дис. на здобуття наук. ступеня канд. філолог. наук : спец. 10.02.02 «Російська мова» / Л. В. Педченко. - Харків, 2000. - 19 с.

21. Потебня А. А. Символ и миф в народной культуре / Александр Афанасьевич Потебня. - М. : Лабиринт, 2000. - 480c.

22. Пустовіт Л. О. Словник української поезії другої половини XX століття : семантикофункціональний аспект : [монографія] / Любов Омелянівна Пустовіт / упоряд. В. І. Матюша, П. А. Матюша, І. Л. Михно. - К. : УНВЦ «Рідна мова», 2009. - 243 с.

23. Рудницький Я. Б. Етимологічний словник української мови : у 2-х т. - Вінніпег : Українська Вільна Академія Наук, 1962-1972. - Т. 1 (випуски 1-11) : А-Г. - 1962-1972. - 530 с.

24. Словник української мови : в 11 т. / АН УРСР, Ін-т мовозн. ім. О. О. Потебні ; [голов. ред. І. К. Білодід]. - К. : Наукова думка, 1970-1980. - Т. 1 : А-В. - 1970. - 800 с.

25. Срезневский И. И. Матеріалы для словаря древне-русскаго языка : в 3 т. - СПб. : Типограф. Император. Академіи наукъ, 1893-1903. - Т. 1 : А-К. - 1893. - 1420 стб.

26. Тресиддер Дж. Словарь символов / Джек Трессидер / [пер. с англ. С. Палько]. - М. : ФАИРПРЕСС, 1999. - 448 с.

27. Трофимова А. В. Концепт «огонь» в современном русском языке : дисс. кандидата филолог. наук : 10.02.01 / Трофимова Антонина Владимировна. - М., 2005. - 211 с. 
28. Трубачев О.Н. Этногенез и культура древнейших славян. Лингвистические исследования / Олег Николаевич Трубачев. - [2-е изд.]. - М. : Наука, 2003. - 489 с.

29. Фасмер М. Этимологический словарь русского языка : в 4 т. / [пер. с. нем. и доп. О. Н. Трубачева]. - [2-е изд., стер.]. - М. : Прогресс, 1986. - Т. 1 : А-Д. - 1986. - 576 с.

30. Хайруллина Д. Д. Концепт «огонь' в английском и татарском языковом сознании (из опыта проведения ассоциативного эксперимента) / Д. Д. Хайруллина // Вестник Челябинского государственного университета. - 2009. - № 17 (155). - Вып. 32. - С. 81-84 (Серия : Филология. Искусствоведение).

31. Чендей Н. В. Поетико-когнітивний потенціал метафор стихій в англійській та українській мовах : автореф. дис. на здобуття наук. ступеня канд. філолог. наук : спец. 10.02 .17 «Порівняльноісторичне і типологічне мовознавство» / Н. В. Чендей. - К., 2009. - 20 с.

32. Черных П. Я. Историко-этимологический словарь современного русского языка : в 2 т. - [3-е изд., стер.]. - М. : Русский язык, 1999. - Т. 1 : А-Пантомима. - 1999. - 624 с.

33. Яковенко І. В. Стихія вогню в прозі Фленнері О’Коннор / I. В. Яковенко // Мовні і концептуальні картини світу. - 2002. - № 7. - С. 549-555.

34. 100 найвідоміших образів української міфології / [Завадська В., Музиченко Я., Таланчук О., Шалак О.]. - К. : Орфей, 2002. - 448 с. 